Wierzbicki S. Evaluation of the effectiveness of on-board diagnostic systems in controlling exhaust gas emissions from motor vehicles.

\title{
EVALUATION OF THE EFFECTIVENESS OF ON-BOARD DIAGNOSTIC SYSTEMS IN CONTROLLING EXHAUST GAS EMISSIONS FROM MOTOR VEHICLES
}

\author{
Slawomir WIERZBICKI \\ University of Warmia and Mazury in Olsztyn, Faculty of Technical Sciences, \\ 11 Oczapowskiego St., 10-957 Olsztyn, Poland, e-mail: slawekw@uwm.edu.pl
}

Abstract

Toxic exhaust gas emissions from internal combustion engines pose the key barrier to vehicle development. Direct measurements of emission levels and toxic compounds present in exhaust gas pose a technical challenge, which is why vehicle emissions are determined by monitoring the parameters of various systems and components. On-board diagnostic systems support engine monitoring in real time. Most onboard diagnostic systems are standardized, therefore their functions can be modified relatively easily. This paper analyzes the functions of the existing on-board diagnostic systems and proposes solutions that prevent unauthorized tampering with vehicle emission systems.

Keywords: on-board diagnostic system, certification test, control system, exhaust gas emissions

\section{OCENA EFEKTYWNOŚCI SYSTEMU DIAGNOSTYKI POKŁADOWEJ POJAZDÓW SAMOCHODOWYCH W ASPEKCIE OCHRONY ŚRODOWISKA}

\section{Streszczenie}

Problem emisji związków toksycznych przez silniki spalinowe jest obecnie podstawową barierą rozwoju pojazdów samochodowych. $\mathrm{Z}$ uwagi na trudne technicznie do realizacji metody bezpośredniego określania poziomu rzeczywistej emisji poszczególnych związków toksycznych, poziom ich emisji przez pojazdy samochodowe $\mathrm{w}$ warunkach eksploatacji określa się na podstawie monitorowania parametrów pracy poszczególnych układów/elementów. Stosowane obecnie w pojazdach samochodowych systemy diagnostyki pokładowej z jednej strony pozwalają na bieżącą kontrolę pracy silnika, a z drugiej strony zaś ze względu na znormalizowaną zasadę działania pozwalają na relatywnie prostą ingerencję $\mathrm{w}$ ich działanie. $\mathrm{W}$ artykule dokonano analizy funkcjonowania obecnie stosowanych pokładowych systemów diagnostycznych oraz zaproponowano kierunki ich rozwoju pozwalające na ograniczenie ingerencji w ich działanie.

Słowa kluczowe: system diagnostyki pokładowej, test homologacyjny, układ sterujący, emisja spalin

\section{INTRODUCTION}

Vehicle transport is a significant source of toxic compound and greenhouse gas emissions to ambient air. The above can be attributed mainly to the fact that internal combustion engines powered by fossil fuels are the primary transportation movers in the contemporary world.

In principle, exhaust gas emissions from modern vehicles are controlled and evaluated:

- during the manufacturing process, where vehicles are certified for compliance with the relevant standards before they are approved for commerce and operation;

- during vehicle operation, where on-board diagnostic systems monitor the operation of systems responsible for exhaust gas emissions;

- during periodic motor vehicle inspections in diagnostic stations;

- during additional inspections in suitably equipped motor vehicle stations upon the request of the authorities responsible for motor vehicle control.

Since the 1980s, considerable advances have been made in the design and structure of internal combustion engines, in particular in exhaust and fuel injection systems - which directly influence exhaust gas emissions New legal regulations are being introduced to enforce the implementation of advanced solutions that limit toxic compound emissions to ambient air. The progress made in electronic control systems contributes to the above goal by enabling accurate control over different components and systems and by facilitating monitoring functions. However, electronic control systems can be easily bypassed to modify a vehicle's operating parameters, which can lead to increase of exhaust emissions.

This article analyzes the threats associated with electronic control systems that can increase exhaust gas emissions from motor vehicles, and discusses 
the current trends in the development of such systems.

\section{CHANGES IN LEGAL REGULATIONS CONCERNING EXHAUST GAS EMISSIONS}

The problems associated with exhaust gas emissions from motor vehicles have been recognized already in the 1950s [9]. Initially, these problems affected large urban areas in highly industrialized countries where exhaust gas emissions contributed to smog during adverse weather conditions. These challenges led to the introduction of legal regulations placing vehicle manufacturers under an obligation to reduce toxic compounds emissions. The development of internal combustion engines and fuel supply systems as well as the rapid increase in motor traffic prompted the introduction of increasingly stringent emission standards. The changes in legal regulations relating to emission standards in vehicles with internal combustion engines in Europe are presented in Table $1[5,6]$.

Table. 1. European emission standards for passenger cars with internal combustion engines $[5,6]$

\begin{tabular}{ccccccc}
\hline $\begin{array}{c}\text { Emission } \\
\text { standard }\end{array}$ & $\begin{array}{c}\text { EURO } \\
1\end{array}$ & $\begin{array}{c}\text { EURO } \\
2\end{array}$ & $\begin{array}{c}\text { EURO } \\
3\end{array}$ & $\begin{array}{c}\text { EURO } \\
4\end{array}$ & $\begin{array}{c}\text { EURO } \\
5\end{array}$ & $\begin{array}{c}\text { EURO } \\
6\end{array}$ \\
\hline $\begin{array}{c}\text { Introduced } \\
\text { on }\end{array}$ & 1993 & 1997 & 2001 & 2006 & 2011 & 2015 \\
\hline $\mathrm{CO}[\mathrm{g} / \mathrm{km}]$ & 2,72 & 1 & 0,64 & 0,5 & 0,5 & 0,5 \\
\hline $\mathrm{HC}[\mathrm{g} / \mathrm{km}]$ & - & - & - & - & - & - \\
\hline $\begin{array}{c}\mathrm{NOx} \\
{[\mathrm{g} / \mathrm{km}]}\end{array}$ & - & - & 0,5 & 0,25 & 0,18 & 0,08 \\
\hline $\begin{array}{c}\mathrm{HC}+\mathrm{NOx} \\
{[\mathrm{g} / \mathrm{km}]}\end{array}$ & 0,97 & 0,7 & 0,56 & 0,3 & 0,23 & 0,17 \\
\hline $\mathrm{PM}[\mathrm{g} / \mathrm{km}]$ & 0,14 & 0,08 & 0,05 & 0,025 & 0,005 & 0,005 \\
\hline
\end{tabular}

As demonstrated in Table 1, increasingly rigorous standards relating to the emissions of different toxic compounds have been introduced in the last 25 years. Particulate matter (PM) emissions were most considerably reduced, and the emission levels under Euro 5 and Euro 6 standards are equivalent to 1/28 of the values approved under the Euro 1 standard. Such a dramatic decrease in exhaust gas emissions has been achieved due to the development of new technologies for controlling fuel supply in engines as well as advanced exhaust aftertreatment systems

However, real-world emissions from internal combustion engines significantly deviate from the approved limits. These discrepancies can be attributed mainly to the absence of simple and reliable methods for measuring the proportions of toxic compounds in exhaust gas. Exhaust gas emissions from motor vehicles can be accurately and reliably determined only during tests on chassis dynamometers equipped with specialized devices for measuring real emissions of toxic compounds.

The New European Driving Cycle (NEDC) was introduced in 1997 to reliably determine the emissions of different toxic compounds and to monitor fuel consumption [10]. The NEDC test supports comparisons of the real performance of various vehicles under identical operating conditions. The stages of the NEDC test (fig. 1) and testing conditions have to conform to strict guidelines. This approach has been introduced to compare the performance of different vehicles, but it also limits the extent to which vehicles are tested to the conditions described in the vehicle certification test.

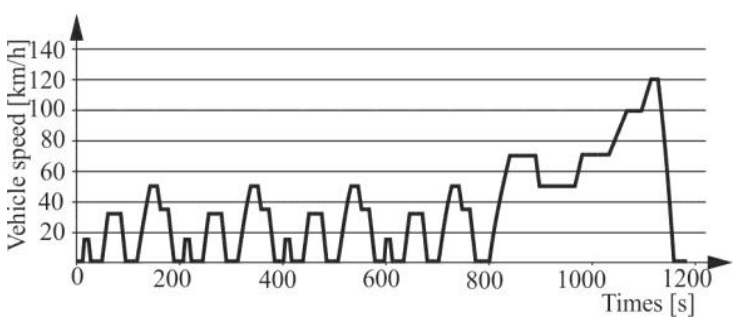

Fig. 1. Stages of the NEDC test [10]

The implementation of NEDC standards in vehicle certification tests forced engine manufacturers to conform to increasingly rigorous emission requirements. As a result, various engine solutions have been developed to improve performance during the certification test. This approach has contributed to a growing discrepancy between fuel consumption and emissions measured during the test and the vehicle's real performance. According to some experts, the discrepancy between measured and real values could be as high as $40-50 \%$ [8]. The rigorous NEDC protocol has also prompted some engine manufacturers to introduce illegal modifications to engine control software to improve their products' performance during the test [1]. The Worldwide Harmonized Light-Duty Vehicle Test Procedure (WLTP) was introduced in 2018 to address the weaknesses of the NEDC and to account for the technological progress in engine control systems. The WLTP driving cycle is presented in fig. 2 [12].

As demonstrated by fig. 2, the WLTP is a far more complex procedure than the NEDC. The WLTP covers more than double the distance of an NEDC cycle. The average and maximum driving speed has been increased, and the proportion of non-urban driving cycles has been increased from $34 \%$ in the NEDC to $48 \%$ in the WLTP. The WLTP better reflects modern driving because it accounts for more dynamic changes in vehicle speed Idling time has been reduced by $50 \%$. Certification requirements have been introduced for every engine, drivetrain and equipment configuration which can affect fuel consumption and emissions. 


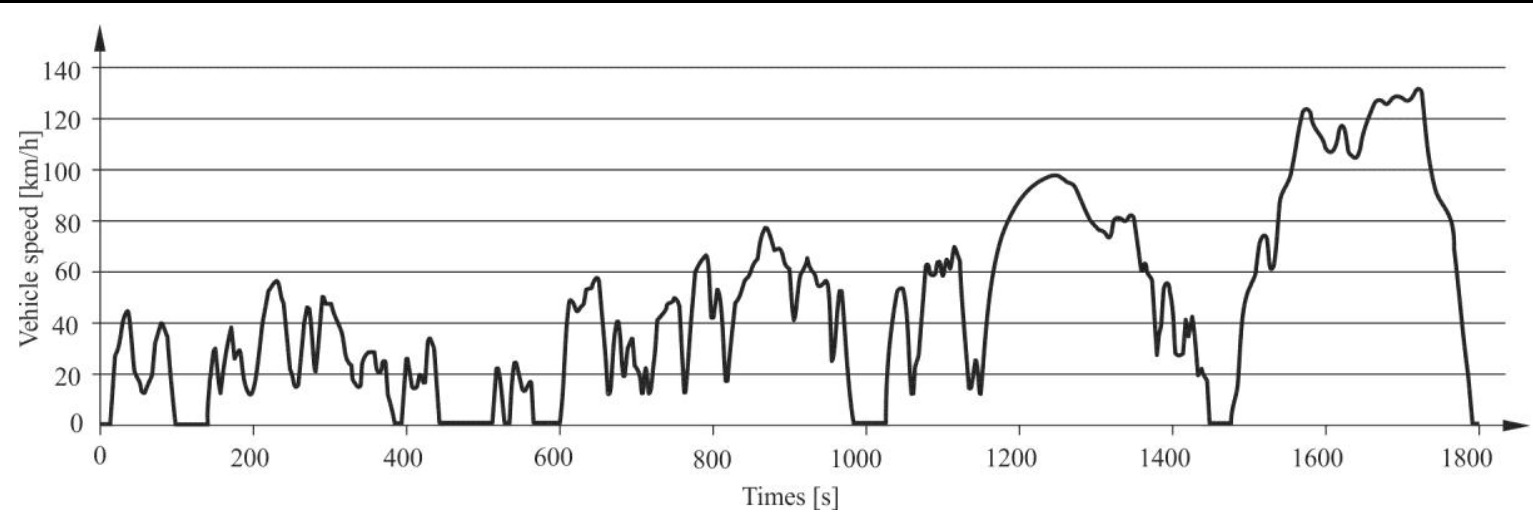

Fig. 2. WLTP driving cycle [12]

Table 2. A comparison of NEDC and WLTP protocols [13]

\begin{tabular}{lcc}
\hline Parameters & NEDC & WLTP \\
\hline Duration $(\mathrm{s})$ & 1180 & 1800 \\
\hline Distance $(\mathrm{km})$ & 11.03 & 23.27 \\
\hline Average speed $(\mathrm{km} / \mathrm{h})$ & 33.6 & 46.5 \\
\hline Maximum speed $(\mathrm{km} / \mathrm{h})$ & 120.0 & 131.3 \\
\hline Stop duration $(\%)$ & 23.7 & 12.6 \\
\hline Constant driving $(\%)$ & 40.3 & 3.7 \\
\hline Acceleration $(\%)$ & 20.9 & 43.8 \\
\hline Deceleration $(\%)$ & 15.1 & 39.9 \\
\hline $\begin{array}{l}\text { Average positive acceleration } \\
\text { (m/s })\end{array}$ & 0.59 & 0.41 \\
\hline $\begin{array}{l}\text { Maximum positive acceleration } \\
\text { (m/s })\end{array}$ & 1.04 & 1.67 \\
\hline $\begin{array}{l}\text { Average positive } \\
\text { "speed*acceleration" }\left(\mathrm{m}^{2} / \mathrm{s}^{3}\right)\end{array}$ & 1.04 & 1.99 \\
\hline $\begin{array}{l}\text { Maximum positive } \\
\text { "speed*acceleration" }\left(\mathrm{m}^{2} / \mathrm{s}^{3}\right)\end{array}$ & 9.22 & 21.01 \\
\hline Average deceleration $\left(\mathrm{m} / \mathrm{s}^{2}\right)$ & -0.82 & -0.45 \\
\hline Minimum deceleration $\mathrm{n}\left(\mathrm{m} / \mathrm{s}^{2}\right)$ & -1.39 & -1.50 \\
\hline
\end{tabular}

According to many researchers, the new certification standards force manufacturers to adopt a more rigorous approach to reducing exhaust gas emissions to ambient air.

\section{EMISSION MONITORING DURING VEHICLE OPERATION}

The sole purpose of a certification test is to evaluate a vehicle's performance and confirm its roadworthiness. During vehicle operation, the proportions of toxic compounds in exhaust gas are determined by fuel quality and the vehicle's technical condition. At present, a vehicle's condition and emission levels are monitored by onboard diagnostic (OBD) systems. In the initial stages of OBD development in the 1980s, different diagnostic standards were applied by individual manufacturers, and OBD systems could be reliably tested only in inspection stations equipped with specialist devices and software. In 1996, the OBD II standard was introduced in the USA to address increasingly rigorous emission standards and the advancements made in electronic control systems. In Europe, OBD II was adapted to the existing regulations, which gave rise to the European On-
Board Diagnostic (EOBD) standard. The EOBD implementation schedule for passenger cars in the European Union is presented in fig. 3 [10].

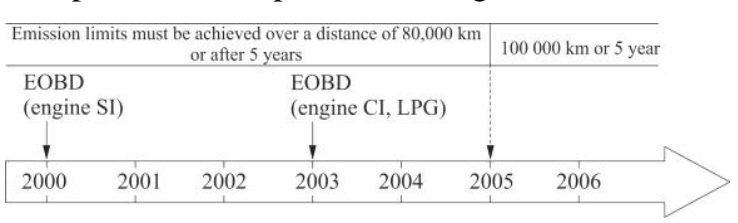

Fig. 3. EOBD implementation schedule for passenger cars in the $\mathrm{EU}[10,18]$

On-board diagnostic systems monitor the following systems:

- engine control system (including: injection, cooling, camshaft timing systems, etc).

- monitoring of the combustion process (including: misfiring, or lack of ignition, oxygen sensors operation and auxiliary air supply);

- malfunction indicators (Malfunction Indicator Light) and data frames containing detailed information about the malfunction;

- standardized digital communications port for diagnosing a vehicle's condition.

Speculations relating to the introduction of a new-generation OBD III standard have been mounting in the literature for many years $[10,15]$. The new system will not only monitor exhaust gas emissions in real time, but it will also have a possibility to notify the responsible authorities of excessive emissions and malfunctions that pose a threat to the safety of the driver or environment. At present, emission monitoring in vehicles poses a considerable technical challenge, and the existing OBD systems, such as the European eCall system, only alert emergency services in the event of a serious accident.

\section{AN ASSESSMENT OF THE OBD II STANDARD IN THE LIGHT OF MODERN AUTOMOTIVE STANDARDS}

The OBD II standard was developed and implemented more than 20 years ago, and it does not fully conform to modern standards in the automotive industry. Every system of the modern vehicle, especially respecting to the combustion 
engine from the point of the controller consists of (fig. 4) [19]:

- sensors that collect information about operating parameters and the user's preferences;

- electronic control units (ECUs) that process the received data based on the stored algorithms and transmit control signals to actuators;

- actuator circuits that control actuators based on the control signal received from the ECU.

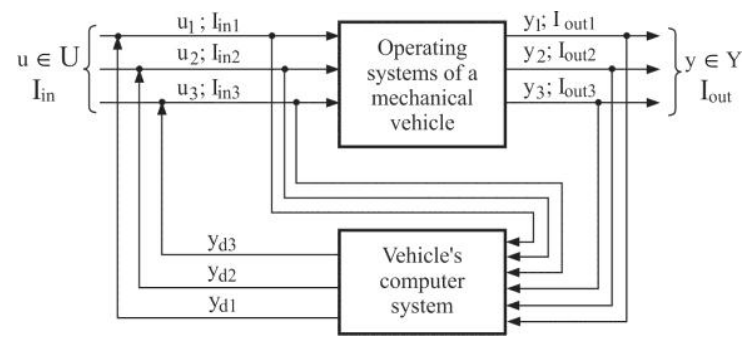

Fig. 4. System control in contemporary mechanical vehicles: $\mathrm{u} \in \mathrm{U}$ - set of input signals, $\mathrm{I}_{\text {in }}$ - input data, $\mathrm{y} \in \mathrm{Y}$ - set of output signals, $\mathrm{I}_{\text {out }}$ - output data, $\mathrm{y}_{\mathrm{i}}\left(\mathrm{I}_{\text {out }}\right)$ - task progress information, $\mathrm{y}_{\mathrm{di}}-$ control signals [19].

These types of control systems are highly accurate, and they can process a large number of control signals to generate output values. Closed loop control algorithms additionally contribute to superior precision of actuator control.

Despite these advantages, electronic control units can be easily modified to provide vast access to the processed data. These data can be used to control and modify a given system, but they can be also used to control and monitor the operation of other systems. Diagnostic systems compliant with the OBD II standard continuously monitor signals from sensors that control the operation of various systems, as well as sensors that are used in other systems, in particular the fuel injection system. The system initiates a malfunction detection procedure when the transmitted signals exceed threshold values. Depending on the type of the identified problem, the malfunction can be communicated to the user or a troubleshooting procedure can be initiated. The troubleshooting procedure in OBD systems has been widely described in the literature $[10,15]$.

Electronic control units are the main components injection and OBD systems. Based on the received data, ECUs control actuators and monitor/diagnose different control circuits. The design of ECUs has evolved considerably in recent years. At the time when the OBD II was introduced, ECUs were designed as closed structures to prevent any changes in their configuration. In modern ECUs, software can be modified to enable periodic updates. Manufacturers are legally obliged to protect ECU software against illegal data tampering. However, the introduced actions are not effective, and numerous tools and user interfaces that support easy modification of ECU software are available on the market. These tools enable users to alter ECU software through remapping, changing limiter values or disabling selected functions in OBD II-compliant systems. In most cases, ECUs are remapped to increase engine power, whereas monitoring functions are generally disabled to accommodate commonly exceeded emission parameters. The existing tools enable users to disable the diagnostic procedures of catalytic converters, particulate matter filters and exhaust gas recirculation (EGR) systems. Tuning boxes can be used to modify a vehicle's operating parameters without altering ECU software. These devices are applied to change sensor and ECU settings to enhance engine performance or disable monitoring functions in selected components and systems, such as catalytic converters. The functions of tuning boxes are discussed in greater detail in the literature [14, 19].

The problems posed by unauthorized modification of a vehicle's performance could be resolved by deviation from the existing approach to engine control. Remapping solutions support quick and easy management of a vehicle's control systems, but they also enable unwanted tampering. The replacement of the existing control protocols with highly advanced solutions, including artificial intelligence methods, would improve engine control, while minimizing the risk of unauthorized access to essential engine systems.

Active tests should be introduced not only to monitor, but also to diagnose the operation of ECUs that control exhaust gas emissions. The functions of the existing OBD systems are limited to monitoring operating parameters of different components and systems. Active tests that periodically inspect a system's response to the programmed default values rather than real-world data would significantly expand the diagnostic functionalities of OBD systems. Intelligent sensors could also be implemented to prevent the installation of sensor simulators. Intelligent sensors display information about the monitored signal, they communicate with the ECU according to a preset protocol, and regularly respond to ECU inquires. Encoded information about the monitored signal and its origin practically rules out the use of sensor simulators.

\section{CONCLUSIONS}

The results of the presented analysis clearly indicate that the existing solutions for monitoring exhaust gas emissions in vehicles with internal combustion engines do not meet contemporary requirements in the automotive industry. In the WLTP, exhaust gas emissions can be evaluated at the stage of vehicle certification, but on-board diagnostic systems compliant with the OBD II standard are susceptible to unwanted tampering. The systems that monitor exhaust gas emissions in a vehicle can be relatively easily disabled. 
Exhaust gas emissions cannot be continuously monitored for technical reasons, therefore emission levels are measured indirectly by analyzing the operation of different system components. Vehicle users have access to various tools and software solutions that mask system malfunctions and are not detected by on-board diagnostic systems. These malfunctions may also be difficult to detect during routine vehicle inspections.

The existing engine control systems should be modified, including with the use of artificial intelligence methods, and instantaneous signal processing should be replaced by continuous-time signal processing to improve the diagnostic accuracy of systems that monitor exhaust gas emissions to ambient air. Critical components and the relevant sensors should be replaced with intelligent sensors that communicate directly with the ECU and prevent the installation of simulators that disrupt their operation.

\section{REFERENCES}

1. Andersen O, Upham P, Aall C. Technological response options after the VW Diesel scandal: implications for engine $\mathrm{CO}_{2}$ emissions. Sustainability. 2018;10(7):1-18; https://doi.org/10.3390/su10072313

2. Czech P, Turoń K, Barcik J. Autonomous vehicles: basic issues. Scientific Journal of Silesian University of Technology. Series Transport. 2018; 100:15-22. https://doi.org/10.20858/sjsutst.2018.100.2.

3. Elmaghraby AS, Losavio MM. Cyber security challenges in Smart Cities: Safety, security and privacy. Journal of Advanced Research, 2014;5(4): 491-497. http://dx.doi.org/10.1016/j.jare.2014.02.006

4. Gis, W, Gis M, Wiśniowski P, Bednarski M. Comparative tests of a passenger car with compression ignition engine on chassis dynamometer during NEDC and WLTC tests and during RDE road test. Combustion Engines. 2019; 178(3): 228-234. http://dx.doi.org/10.19206/CE-2019-340.

5. Idzior M, Czapliński E. Wpływ ograniczeń prawnych i systemów technicznych na ograniczenie emisji toksycznych. Autobusy: technika, eksploatacja, systemy transportowe. 2018; 19(6): 473-477. https://dx.doi.org/10.24136/atest.2018.115.

6. Jacyna M, Pyza D. Decision-making problems in shaping the sustainable development of the transport system. Autobusy - Technika, Eksploatacja, Systemy Transportowe. 2019;231(6):61-67. https://dx.doi.org/10.24136/atest.2019.12

7. Merkisz J, Rychter M. OBD II system as a future diagnostic method of vehicles. Eksploatacja i Niezawodność. 2002; 1:38-51.

8. Merkisz J, Andrzejewski M, Pielecha J. Porównanie emisji dwutlenku węgla w rzeczywistych warunkach ruchu pojazdu z wartościami uzyskiwanymi w teście homologacyjnym na tle norm europejskich. Silniki Spalinowe. 2011; 50(3):1-9.

9. Merkisz J, Walasik S. Uwagi o przepisach dotyczących emisji związków toksycznych spalin $\mathrm{z}$ silników pojazdów o zastosowaniach pozadrogowych. Archiwum Motoryzacji. 2006; 1: 41-51.
10. Merkisz J, Mazurek S. Pokładowe systemy diagnostyczne pojazdów samochodowych. WKŁ, Warszawa, 2007.

11. Mikulski M, Wierzbicki S, Piętak A. Zerodimensional 2-phase combustion model in a dual-fuel compression ignition engine fed with gaseous fuel and a divided diesel fuel charge. Eksploatacja i Niezawodność - Maintenance and Reliability. 2015:17(1):42-48. http://dx.doi.org/10.17531/ein.2015.1.6.

12. Mock P, Kühlwein J, Tietge U, Franco V, Bandivadekar A, German J. The WLTP: How a new test procedure for cars will affect fuel consumption values in the EU. ICCT White Paper, 2014. http://www.theicct.org/sites/default/files/publications/ ICCT_WLTP_EffectEU_20141029.pdf.

13. Pavlovic J, Ciuffo B, Fontaras G, Valverde V, Marotta A. How much difference in type-approval $\mathrm{CO}_{2}$ emissions frompassenger cars in Europe can be expected from changing tothe new test procedure (NEDC vs. WLTP)?. Transportation Research Part A: Policy and Practice. 2018; 111:136-147. https://doi.org/10.1016/j.tra.2018.02.002.

14. Prajwowski K. Impact of an external, so called box, module on power and torque of the FIAT 1.3 JTD MOTOR. Journal of KONES Powertrain and Transport. 2012; 19(1):327-332.

15. Rokosch U. Układy oczyszczania spalin i pokładowe systemy diagnostyczne samochodów OBD. WKŁ, Warszawa 2006.

16. Szokało AA, Rychter M. Rozwój systemu diagnostyki pokładowej samochodów osobowych w świetle zasady działania systemu OBD. Autobusy Technika, Eksploatacja, Systemy Transportowe. 2018; 220(6):743:746 https://doi.org/10.24136/atest.2018.167.

17. Verner J, Sejkorova M. Comparison of CVS and PEMS measuring devices used for stating $\mathrm{CO}_{2}$ exhaust emissions of light-duty vehicles during WLTP testing procedure. Engineering for Rural Development. 2018. https://doi.org/10.22616/ERDev2018.17.N284

18. Wierzbicki S. Procedury diagnozowania pojazdów samochodowych zgodnych $\mathrm{Z}$ normą OBD II. Diagnostyka. 2003;28:47-52.

19. Wierzbicki S. Evaluation of on-board diagnostic systems in contemporary vehicles. Diagnostyka. 2011;3(59):35-40.

\section{Received 2019-07-05}

Accepted 2019-11-26

Available online 2019-11-28

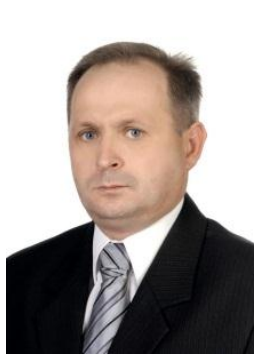

Ph.D., D.Sc. Slawomir

WIERZBICKI - professor at the Department of Mechatronics. He is also Deputy Dean of the Faculty of Technical Sciences of the UWM in Olsztyn and Head of the Department of Mechatronics.

In his work, he deals with fuelling modern self-ignition combustion engines and electronic systems which supervise the operation and diagnostics of vehicles and machinery.

$\mathrm{He}$ is a member of the Polish Technical Diagnostics Association, Polish Scientific Combustion Engines Association and the Polish Scientific and Technical Maintenance Association. 